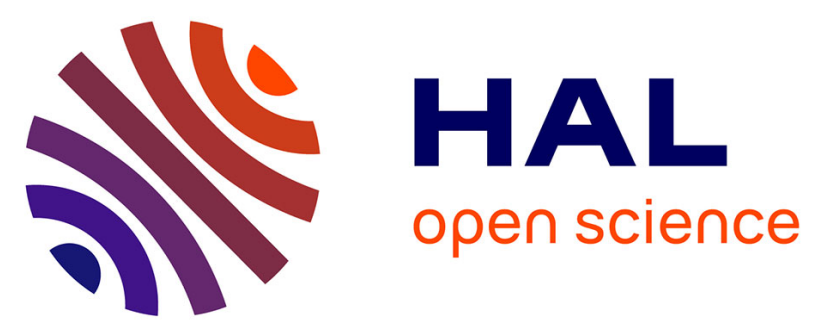

\title{
Serological response to pgp3 protein in animal and human chlamydial infections
}

Manuela Donati, Karine Laroucau, Elisa Storni, Costanza Mazzeo, Simone

Magnino, Antonietta Di Francesco, Raffaella Baldelli, Letizia Ceglie, Maria

Renzi, Roberto Cevenini

\section{To cite this version:}

Manuela Donati, Karine Laroucau, Elisa Storni, Costanza Mazzeo, Simone Magnino, et al.. Serological response to pgp3 protein in animal and human chlamydial infections. Veterinary Microbiology, 2009, 135 (1-2), pp.181. 10.1016/j.vetmic.2008.09.037 . hal-00532491

\section{HAL Id: hal-00532491 \\ https://hal.science/hal-00532491}

Submitted on 4 Nov 2010

HAL is a multi-disciplinary open access archive for the deposit and dissemination of scientific research documents, whether they are published or not. The documents may come from teaching and research institutions in France or abroad, or from public or private research centers.
L'archive ouverte pluridisciplinaire $\mathbf{H A L}$, est destinée au dépôt et à la diffusion de documents scientifiques de niveau recherche, publiés ou non, émanant des établissements d'enseignement et de recherche français ou étrangers, des laboratoires publics ou privés. 


\section{Accepted Manuscript}

Title: Serological response to pgp3 protein in animal and human chlamydial infections

Authors: Manuela Donati, Karine Laroucau, Elisa Storni, Costanza Mazzeo, Simone Magnino, Antonietta Di Francesco, Raffaella Baldelli, Letizia Ceglie, Maria Renzi, Roberto

Cevenini

PII:

DOI:

Reference:

S0378-1135(08)00406-9

doi:10.1016/j.vetmic.2008.09.037

VETMIC 4191

To appear in: $\quad$ VETMIC

Please cite this article as: Donati, M., Laroucau, K., Storni, E., Mazzeo, C., Magnino, S., Di Francesco, A., Baldelli, R., Ceglie, L., Renzi, M., Cevenini, R., Serological response to pgp3 protein in animal and human chlamydial infections, Veterinary Microbiology (2008), doi:10.1016/j.vetmic.2008.09.037

This is a PDF file of an unedited manuscript that has been accepted for publication. As a service to our customers we are providing this early version of the manuscript. The manuscript will undergo copyediting, typesetting, and review of the resulting proof before it is published in its final form. Please note that during the production process errors may be discovered which could affect the content, and all legal disclaimers that apply to the journal pertain. 


\section{Serological response to pgp3 protein in animal and human chlamydial infections}

Manuela Donati ${ }^{\mathrm{a}^{*}}$, Karine Laroucau $^{\mathrm{b}}$, Elisa Storni ${ }^{\mathrm{a}}$, Costanza Mazzeo ${ }^{\mathrm{a}}$, Simone Magnino ${ }^{\mathrm{c}}$, Antonietta Di Francesco $^{\mathrm{d}}$, Raffaella Baldelli ${ }^{\mathrm{d}}$, Letizia Ceglie ${ }^{\mathrm{e}}$, Maria Renzi ${ }^{\mathrm{f}}$, Roberto Cevenini ${ }^{\mathrm{a}}$.

${ }^{a}$ Section of Microbiology, DMCSS, University of Bologna, S. Orsola Hospital, Bologna, Italy; ${ }^{\mathrm{b}}$ French Food Safety Agency, Bacterial Zoonoses Unit, LERPAZ Maison-Alfort, France; ${ }^{\mathrm{c}}$ Istituto Zooprofilattico Sperimentale della Lombardia e dell'Emilia-Romagna, National Reference Laboratory for Animal Chlamydioses, Pavia, Italy; ${ }^{\mathrm{d}}$ Department of Veterinary Public Health and Animal Pathology, University of Bologna, Ozzano Emilia, Bologna, Italy; ${ }^{\mathrm{I}}$ Istituto Zooprofilattico Sperimentale delle Venezie, Legnaro, Padova, Italy; ${ }^{\mathrm{f}}$ Istituto Zooprofilattico Sperimentale della Lombardia e dell'Emilia-Romagna, Bologna.

*Corresponding Author. Mailing address:

Manuela Donati, M.D.

Sezione di Microbiologia, DMCSS, Policlinico S. Orsola, Università di Bologna, Via Massarenti 9, 40138 Bologna, Italy. Phone: 39 0514290944. Fax: 39051 307397. E-mail: manuela.donati@unibo.it

\footnotetext{
Abstract

Specific antibodies to plasmid-encoded protein pgp3 are known to be encountered in human Chlamydia $(C$.) trachomatis infections. In order to verify whether antibodies to this protein could be developed in animals infected with plasmid-carrying chlamydial strains, 454 animal sera were examined using a home-made pgp3 protein ELISA and Western blots (WB) of recombinant pgp3 protein from Chlamydophila $(C p$.) psittaci. Likewise, 50 human sera were tested by ELISA and WB of recombinant pgp3 from $C$. trachomatis. The reactivity against pgp3 protein was compared to the
} 
reactivity against chlamydial elementary bodies (EBs) detected by microimmunofluorescence (MIF) test. The presence of pgp3-specific antibodies was demonstrated in most ducks and pigeons with $C p$. psittaci infection detected by MIF, as well as in the majority of symptomatic cats and pigs infected with $C p$. felis and $C$. suis, respectively, which reacted at high titres to $C p$. felis and $C$. suis EBs by MIF. Moreover, most of the sera collected from patients with C. trachomatis cultureconfirmed infection and seropositive to $C$. trachomatis by MIF, presented antibodies specific to $C$. trachomatis pgp3 recombinant protein. Therefore, pgp3 protein could be a useful marker of chlamydial infections in animals, as well as in humans.

Keywords: pgp3 protein, plasmid, ELISA, WB, MIF, chlamydial infection

\section{Introduction}

Members of the family Chlamydiaceae are intracellular pathogens responsible for a wide range of important medical and veterinary diseases. According to Everett et al. (1999) two genera, Chlamydia and Chlamydophila, are recognized in this family, although this classification remains controversial (Schachter et al., 2001). The presence of plasmids has been determined in the majority of strains in the genus Chlamydia and in many Chlamydophila species e.g. the equine strain N16 of Cp. pneumoniae, several strains of Cp. psittaci (Lovett et al., 1980) and some strains of $C p$. felis, $C p$. pecorum and $C p$. caviae. On the contrary, extrachromosomal DNA elements have not been identified in human $C p$. pneumoniae isolates or in isolates of $C p$. abortus.

The existence of some plasmid-free chlamydial strains (An et al., 1992; Farencena et al., 1997), suggests that the plasmid is probably not essential for chlamydial growth and replication. On the other hand, a recent study on the molecular and biological properties of plasmidless and plasmid positive C. trachomatis strains supports a primary role for plasmid in in vivo infectivity and in the control of virulence (Carlson et al., 2008). 
Many studies have described the molecular characterization of chlamydial plasmids (Joseph et al., 1986; Palmer and Falkow, 1986; Sriprakash and MacAvoy, 1987; Hatt et al., 1988; Comanducci et al., 1990) and shown that they are highly conserved. The genomic organization of $C p$. psittaci plasmid accounts for the presence of eight major open reading frames (ORFs), as also observed in C. trachomatis strains (Thomas et al., 1997). All chlamydial plasmids have four 22-pb tandem repeats in the intergenic region between ORF8 and ORF1 (Thomas et al., 1997). Identical plasmid repeat sequences have been shown in avian Cp. psittaci isolates (Hugall et al., 1989), in Cp. felis isolates carrying a plasmid (Lusher et al., 1991) and in Cp. caviae isolates (Lusher et al., 1991). Conserved sequences have also been identified in the plasmid of the equine strain N16 of $C p$. pneumoniae and the type strain E58 of Cp. pecorum (sporadic bovine encephalomyelitis isolate) (Hugall et al., 1989; Everett et al., 1999). In human C. trachomatis isolates, the repeats are identical but show two nucleotide substitutions from the conserved $C p$. psittaci repeat sequence (Thomas et al., 1997).

C. trachomatis ORFs can code for polypeptides greater than $10 \mathrm{kDa}$ and putative functions have been shown for five of them. ORF3, which has been expressed in E. coli, encodes pgp3, a highly antigenic protein of $28 \mathrm{kDa}$ (Comanducci et al., 1988). This protein is a marker of current $C$. trachomatis infection in humans (Comanducci et al., 1994) and can be identified by staining inclusions in C. trachomatis-infected cells.

In addition, DNA immunization with the pgp3 gene of $C$. trachomatis was demonstrated to inhibit the spread of $C$. trachomatis infection from the lower to the upper genital tract in $\mathrm{C} 3 \mathrm{H} / \mathrm{HeN}$ mice (Donati et al., 2003).

In a recent study, we demonstrated a homogeneous restriction profile in the plasmid of 10 avian $C p$. psittaci isolates (Storni et al., 2006). Moreover, in the same work, serum antibodies against recombinant $C p$. psittaci pgp3 protein were detected by Western blot (WB) in a patient with culture-confirmed psittacosis and in $48 C p$. psittaci-infected pigeons. 
In the present study, the serological response to recombinant pgp3 protein of $C p$. psittaci was evaluated by a home-made ELISA and WB in different animal species to detect the infection by plasmid-carrying strains of chlamydiae, i.e. $C p$. psittaci infection in ducks and pigeons, $C p$. felis infection in cats and $C$. suis infection in pigs. In addition, sera collected from humans infected by $C$. trachomatis were tested to detect the presence of antibodies to recombinant pgp3 protein of $C$. trachomatis. The serological reactivity to pgp3 protein of the different animal and human sera was compared to their reactivity in the microimmunofluorescence (MIF) test against $C p$. psittaci, $C p$. felis, C. suis and C. trachomatis elementary bodies (EBs).

\section{Materials and methods}

\subsection{Serum samples}

A total of 454 animal sera and 50 human sera were tested for their reactivity to pgp3 protein. Three hundred and fifty-four of the animal sera were avian: 134 sera were randomly collected from French ducks (from 4 to 14 weeks of age) presenting no specific clinical signs of $C p$. psittaci infection and belonging to seven different flocks depending on their age and 220 sera were taken from otherwise healthy pigeons in Emilia-Romagna (Northern Italy). The remaining 100 sera consisted of 50 feline sera and 50 porcine sera. The feline sera were collected in Emilia-Romagna from 45 household cats suffering from conjunctivitis and 5 cats presenting no clinical signs of $C p$. felis infection. Porcine sera were collected in Emilia-Romagna from 45 pigs with conjunctivitis reared in two different $C$. suis isolation-positive farms and 5 pigs without clinical signs of conjunctivitis, reared in another farm.

The 50 human sera were collected in Emilia-Romagna from C. trachomatis isolation-positive patients (35 men and 15 women). 
The presence of antibodies specific to pgp3 in avian, feline and porcine sera was studied by using a home-made ELISA and WB performed with recombinant pgp3 protein of $C p$. psittaci. The same techniques, performed with pgp3 recombinant protein of $C$. trachomatis were used to detect antibodies to pgp3 in human sera.

The serological reactivity to pgp3 of the 504 sera studied was then compared to their reactivity by MIF against $C p$. psittaci EBs (duck and pigeon sera), $C p$. felis EBs (feline sera), $C$. suis EBs (porcine sera) and C. trachomatis EBs (human sera). The 134 duck sera studied by WB and ELISA had been previously tested in France by complement fixation (CF) test and a commercial ELISA test (Chekit Chlamydia ELISA, Bommeli Idexx) based on detection of chlamydial anti-LPS groupspecific antibodies.

\subsection{MIF}

MIF test was performed by using purified EBs of the following strains: $6 \mathrm{BC}$ of $C p$. psittaci, FEIS-M of $C p$. felis, MS04 of $C$. suis and GO/86 of $C$. trachomatis. The EBs were purified by sucrose density-gradient ultracentrifugation using the method of Fukushi and Hirai (1988). Human sera were screened at 1:16 dilution; animal sera were tested at 1:32 dilution in phosphate-buffered saline (PBS) supplemented with $2 \%$ foetal calf serum. The test was performed according to the method of Wang and Grayston (1986). Serial twofold dilutions of sera found to be positive at cutoff dilution were made and tested to determine the antibody titre.

\subsection{SDS-PAGE and pgp3 Western Immunoblotting}


After expression and purification of the recombinant pgp3 proteins of $C p$. psittaci and $C$. trachomatis as previously described (Storni et al., 2006), sodium dodecyl sulfate-polyacrylamide gel electrophoresis (SDS-PAGE) and electrophoretic transfer were performed (Comanducci et al., 1994), and the blots were incubated overnight with sera under test diluted 1:100 in skimmed milk containing 5\% w/v Tween 20/PBS pH 7.4. After washing, antigen-antibody complexes were detected, depending on the animal sera to be tested, with peroxidase-labelled rabbit anti-duck, antipigeon, anti-pig or anti-cat IgG (Nordic Immunological Laboratories, Tilburg, The Netherlands). When human sera were tested, antigen-antibody complexes were detected with peroxidase-labelled rabbit anti-human IgG (Dako, Glostrup, Denmark).

\section{3. pgp3 ELISA}

IgG anti-pgp3 specific antibody response was determined by direct ELISA. Microtitre plates were coated overnight at $4^{\circ} \mathrm{C}$ with $100 \mu \mathrm{l}$ of pgp3 at the concentration of $6 \mu \mathrm{g} / \mathrm{ml}$ in carbonate buffer $\mathrm{pH}$ 9.6, then blocked with skimmed milk $5 \% \mathrm{w} / \mathrm{v}$ in carbonate buffer $\mathrm{pH} 9.6$. In subsequent stages, the wells received $100 \mu \mathrm{l}$ of reagents diluted in skimmed milk containing 5\% w/v Tween 20/PBS pH 7.4. All sera diluted 1:100 were assayed in duplicate. Each plate assayed included replicate dilutions of two reference sera with known activity. The plates were incubated at $37^{\circ} \mathrm{C}$ for 60 min., then washed three times and incubated with a 1:1000 dilution of alkaline phosphatase-conjugated goat antibody anti-duck or anti-pigeon or anti-cat or anti-pig IgG (Nordic Immunological Laboratories) or anti-human $\operatorname{IgG}$ (Dako), depending on the sera to be tested. After incubation for $60 \mathrm{~min}$ at $37^{\circ} \mathrm{C}$, the plates were washed three times and the alkaline phosphatase substrate paranitrophenylphosphate was added. After incubation at room temperature for $20 \mathrm{~min}$, the reaction was stopped by adding $3 \mathrm{M} \mathrm{NaOH}$ and the plates were read at a wavelength of $405 \mathrm{~nm}$. A positive sample was defined as a sample that yielded an $\mathrm{OD}_{405}$ value of at least two standard deviations above the mean of 20 
negative samples. In addition, a MIF positive control serum for each species tested was introduced in each experimental session.

Twofold dilutions from 1:100 of the MIF positive control serum and 5 positive pgp3 ELISA sera for each species were tested to compare their dilution curve.

\section{Results}

The serum reactivities to pgp3 determined by the home-made ELISA and WB in comparison to the serological reactivities to chlamydial EBs tested by MIF are reported in Table 1.

An OD of $\geq 0.5$ was considered the cut-off value. The OD405/serum dilution curve of 5 sera in each species tested was comparable to that obtained with the MIF positive control serum.

The recombinant $C p$. psittaci pgp3 ELISA detected IgG antibodies in $59(78.7 \%)$ out of 75 sera collected from ducks of $8,11,13,14$ weeks of age living in four different flocks. The WB demonstrated reactivity to pgp3 in $56(74.7 \%)$ sera. Sixty $(80.0 \%)$ out of the 75 sera resulted positive by MIF at titres ranging from 64 to 256. On the other hand, IgG antibodies to LPS chlamydial antigen were detected by Chekit commercial ELISA in only $34(45.3 \%)$ of the 75 sera tested. These ducks were also tested for $C p$. psittaci excretion, where 24 (32\%) of 75 coacal swabs resulted positive by PCR.

Out of the 59 sera collected in another three different flocks from very young ducks $(4,5$ and 6 weeks old), in which no antibodies to $C p$. psittaci were detected by the commercial Chekit ELISA, only $3(5.1 \%)$ sera resulted positive both by pgp3 ELISA and WB. Ten of these 59 sera (16.9\%) were positive by MIF. Most of these ducks proved negative also for $C p$. psittaci excretion. All 134 duck sera tested were negative by CF test.

IgG anti-pgp3 antibody response was determined by the home-made ELISA and WB in 86 (39.1\%) and $84(38.2 \%)$ of the 220 pigeon sera tested, respectively; $88(40 \%)$ resulted positive by MIF for the presence of antibodies to $C p$. psittaci at titres ranging from 32 to 256 . 
Fourty-four (97.8\%) out of 45 sera collected from cats with conjunctivitis and positive by MIF to Cp. felis at titres ranging from 128 to 512, reacted to pgp3 both in ELISA and WB (concordance of $97.8 \%)$.

All the 45 porcine sera collected from pigs with conjunctivitis reared in C. suis isolation-positive farms and positive by MIF for the presence of antibodies at titres ranging from 128 to 1024 , demonstrated a strong reactivity to pgp3 both by ELISA and WB (concordance of 100\%).

On the contrary, the 10 sera collected from 5 cats and 5 pigs with no signs of conjunctivitis and negative by MIF to $C p$. felis and $C$. suis respectively, were not reactive by pgp3 ELISA and WB assays.

Finally, $33(66 \%)$ out of 50 sera collected from C. trachomatis-isolation positive patients reacted to C. trachomatis pgp3 both in ELISA and WB. Thirty-six (72\%) of these 50 sera were positive by MIF for the presence of antibodies to C. trachomatis EBs. The remaining 14 MIF-negative sera did not react with recombinant pgp3 protein of $C$. trachomatis both in ELISA and WB.

In Table 2, the concordance and discordance between the ELISA, WB and MIF tests in duck, pigeon and human sera are reported. The data obtained by setting MIF as the reference method (gold standard) show that pgp3-ELISA and WB are less sensitive than the MIF test, but are nevertheless very specific techniques.

\section{Discussion}

Humoral immune response to plasmid protein pgp3 in human C. trachomatis infections has been described (Comanducci et al., 1994; Bas et al., 2001a; Bas et al., 2001b). To verify whether animals infected by plasmid-carrying chlamydial strains could develop antibodies against pgp3 protein, 454 animal sera were tested by a home-made ELISA and WB performed with recombinant pgp3 protein of $C p$. psittaci. 
The serological response to pgp3 was compared to the serological reactivity detected by MIF to determine whether pgp3 could be a marker of chlamydial infections in animals as well as in humans.

The presence of antibodies against pgp3 protein was detected in most of the duck and pigeon sera in which $C p$. psittaci infection was documented by their reactivity to $C p$. psittaci EBs in MIF. In addition, the commercial ELISA and the CF test previously used in France on duck sera to detect a chlamydial infection, were shown to be less specific and sensitive than our home-made ELISA and WB based on recombinant pgp3.

Similarly, almost all sera collected from cats with conjunctivitis and strongly reacting in MIF to $C p$. felis presented antibodies to the pgp3 protein.

In addition, a serological response to pgp3 was detected in all sera from pigs reared in C. suis isolation-positive farms, which had also proved positive at high titres to C. suis by MIF.

Finally, almost all sera of patients with $C$. trachomatis culture-confirmed infection, which had been found seropositive for $C$. trachomatis by MIF were reactive with recombinant pgp3 protein of $C$. trachomatis in ELISA and WB.

These results suggest ORF3, the only plasmid ORF found to encode an immunogenic protein in $C$. trachomatis, i.e. pgp3, codes similarly in $C p$. psittaci, $C p$. felis and $C$. suis for a protein that is highly antigenic. This is demonstrated by the finding of serum pgp3 antibody response in the majority of animals, such as ducks, pigeons and symptomatic cats and pigs, which were seropositive for Chlamydia by MIF, as well as by the absence of antibodies to pgp3 in the asymptomatic animals that were serologically negative by MIF.

The present results show that pgp3 can be an immune response target of diagnostic importance. The newly developed ELISA could prove a valuable serological tool, especially in those infections that are caused by only one plasmid-carrying species such as in avian and feline chlamydial infections. In contrast, this ELISA may not have the same diagnostic importance in other cases, such as pig 
infections caused by several, often associated, chlamydial species. Further studies are needed to evaluate the degree of cross-reactivity between the pgp3 proteins of different chlamydial species.

Given that the MIF is a tedious assay requiring a) culture of the relevant chlamydial strains, which is restricted to specialized laboratories, b) serum dilutions, and c) trained personnel and expertise, a novel sensitive and specific ELISA will certainly be of advantage.

\section{Conflict of interest statement}

None declared.

\section{References}

An, Q., Radcliffe, G., Vassallo, R., Buxton, D., O’Brien, W.J., Pellettier, D.A., Weisburg, W.G., Klinger, J.D., Olive, D.M., 1992. Infection with a plasmid-free variant Chlamydia related to Chlamydia trachomatis identified by using multiple assays for nucleic acid detection. J. Clin. Microbiol. 30, 2814-2821.

Bas, S., Muzzin, P., Vischer, T.L., 2001a. Chlamydia trachomatis serology: value of outer membrane protein 2 compared with that of other antigens. J. Clin.Microbiol. 39, 4082-4085.

Bas, S., Muzzin, P., Ninet, B., Bornand, J.E., Scieux, C., Vischer, T.L., 2001b. Chlamydial serology: comparative diagnostic value of immunoblotting, microimmunofluorescence test, and immunoassays using different recombinant proteins as antigens. J. Clin. Microbiol. 39, 1368-1377.

Carlson, J.H., Whitmire, W.M., Crane, D.D., Wicke, L., Vitaneva, K., Sturdevant, D.E., Kupko III, J.J., Porcella, S.F., Martinez-Orengo, N., Heinzen, R.A., Kari, L., Caldwell, H.D., 2008. The Chlamydia trachomatis plasmid is a transcriptional regulator of chromosomal genes and a virulence factor. Infect. Immun. 76, 2273-2283. 
Comanducci, M., Ricci, S., Ratti, G., 1988. The structure of a plasmid of Chlamydia trachomatis believed to be required for growth within mammalian cells. Mol. Microbiol. 2, 531-538.

Comanducci, M., Ricci, R., Cevenini, R., Ratti, G., 1990. Diversity of the chlamydial common plasmid in biovars with different pathogenicity. Plasmid 23, 149-154.

Comanducci, M., Manetti, R., Bini, L., Cantucci, A., Pallini, V., Cevenini, R., Sueur, J.M., Orfila, J., Ratti, G., 1994. Humoral immune response to plasmid protein pgp3 in patients with Chlamydia trachomatis infection. Infect. Immmun. 62, 5491-5497.

Donati, M., Sambri, V., Comanducci, M., Di Leo, K., Storni, E., Giacani, L., Ratti, G., Cevenini, R., 2003. DNA immunization with pgp3 gene of Chlamydia trachomatis inhibits the spread of chlamydial infection from the lower to the upper genital tract in $\mathrm{C} 3 \mathrm{H} / \mathrm{HeN}$ mice. Vaccine 21,1089 1093.

Everett, K. D. E., Bush, R. M., Andersen, A. A., 1999. Emended description of the order Chlamydiales, proposal of Parachlamydiaceae fam. nov. and Simkaniaceae fam. nov., each containing one monotypic genus, revised taxonomy of the family Chlamydiaceae, including a new genus and five new species, and standards for the identification of organisms. Int. J. Syst. Bacteriol. 49, 415-440.

Farencena, A., Comanducci, M., Donati, M., Ratti, G., Cevenini, R., 1997. Characterization of a new isolate of Chlamydia trachomatis which lacks the common plasmid and has properties of biovar trachoma. Infect. Immun. 65, 2965-2969. 
Fukushi, H., Hirai, K.J., 1988. Immunochemical diversity of the major outer membrane protein of avian and mammalian Chlamydia psittaci. J. Clin. Microbiol. 26, 675-680.

Hatt, C., Ward, M.E., Clarke, N., 1988. Analysis of the entire nucleotide sequence of the cryptic plasmid of Chlamydia trachomatis serovar L1. Evidence for involvement in DNA replication. Nucleic Acids Res. 16, 4053-4067.

Hugall, A., Timms, P., Girjes, A.A., Lavin, M.F., 1989. Conserved DNA sequences in chlamydial plasmids. Plasmid 22, 91-98.

Joseph, T., Nano, F.E., Garon, C.F., Caldwell, H.D., 1986. Molecular characterization of Chlamydia trachomatis and Chlamydia psittaci plasmids. Infect. Immun. 51, 699-703.

Lovett, M., Kuo, K.K., Holmes, K., Falkow, S., 1980. Plasmids of the genus Chlamydia. In Current Chemotherapy and Infectious Diseases, vol. 2, pp. 1250-1252. Edited by J. Nelson and C. Grassi. Washington, DC: American Society for Microbiology.

Lusher, M., Storey, C.C., Richmond, S.J., 1991. Extrachromosomal elements of the genus Chlamydia. Adv. Gene Technol. 2, 261-285.

Palmer, L., Falkow, S., 1986. A common plasmid of Chlamydia trachomatis. Plasmid 16, 52-62.

Schachter J., Stephens R.S., Timms P., and 28 other authors, 2001. Radical changes to chlamydial taxonomy are not necessary just yet. Int. J. Syst. Evol. Microbiol. 51, 249. 
Sriprakash, K.S., MacAvoy, E.S., 1987. Characterization and sequence of a plasmid from the trachoma biovar of Chlamydia trachomatis. Plasmid 18, 205-214.

Storni, E., Donati, M., Marangoni, A., Accardo, S., Cevenini, R. 2006. Comparative PCR-based restriction length polymorphism analysis of the plasmid gene orf3 of Chlamydia trachomatis and Chlamydia psittaci. FEMS Immunol. Med. Microbiol. 48, 313-318.

Thomas, N.S., Lusher, M., Storey, C.C., Clarke, I.N., 1997. Plasmid diversity in Chlamydia. Microbiology 143, 1847-1854.

Wang, S.P., Grayston, J.T., 1986. Microimmuno-fluorescence serological studies with the TWAR organism. In: Chlamydial Infections. Proceeding of the Six International Symposium on Human Chlamydial Infection (D. Oriel, G. Ridgway, J. Schachter, and D. Taylor-Robinson, eds.), pp. 329332. Cambridge University Press, Cambridge (1986). 


\section{Table 1.}

Sera reactivities to pgp3 detected by the home-made ELISA and WB techniques in comparison to the serological reactivities to chlamydial EBs tested by MIF

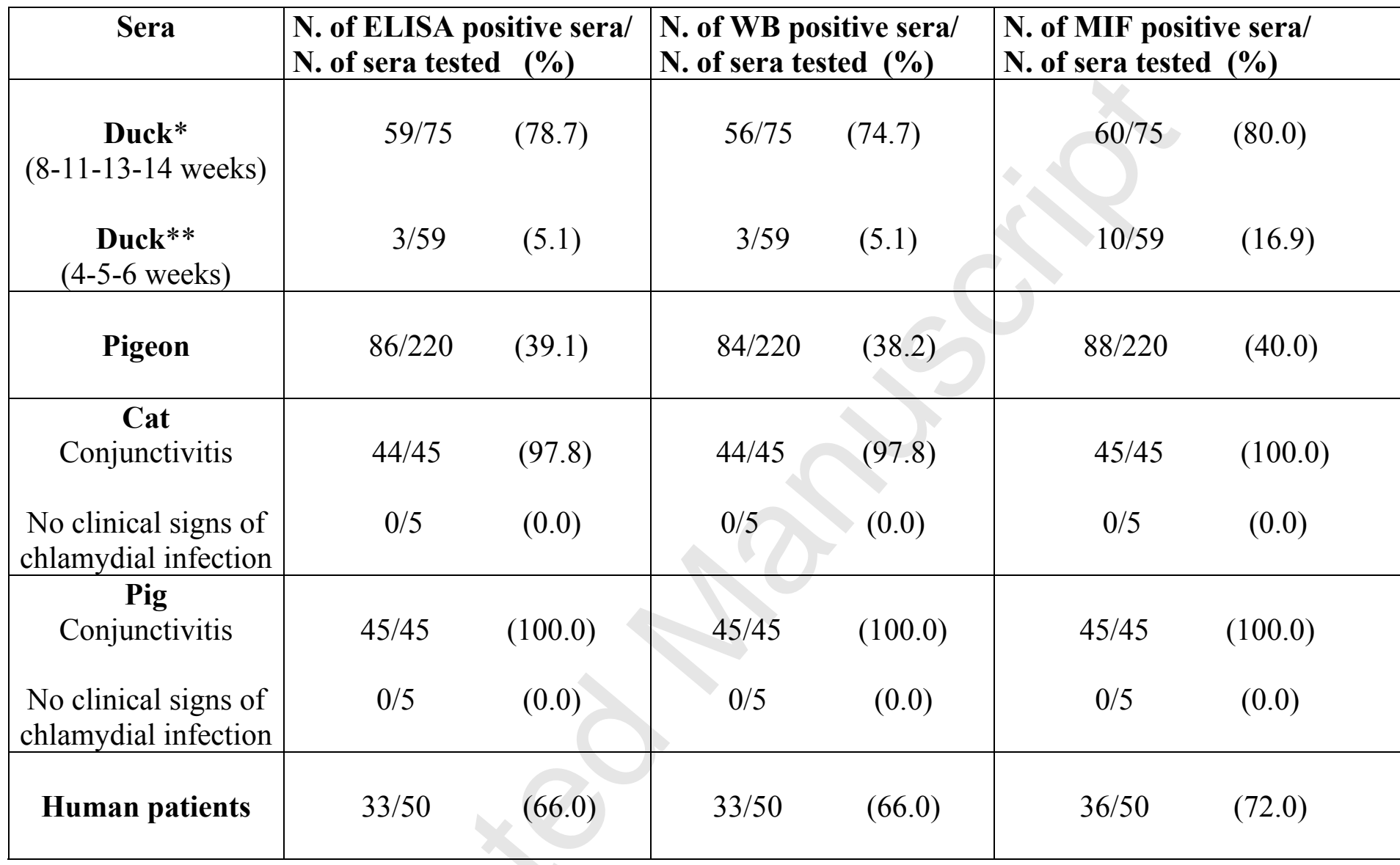

* Positivity to Chekit commercial ELISA: 34/75 (45.3\%) ducks.

** Positivity to Chekit commercial ELISA: 0/75 (0.0\%) ducks.

\section{Table 2.}

Concordance/discordance of sera between ELISA, WB and MIF tests.

pgp3-ELISA

MIF

duck sera

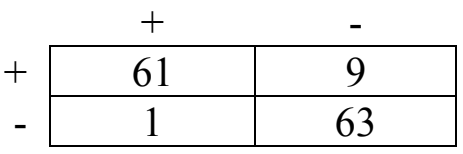

pgp3-WB

\begin{tabular}{|c|c|c|}
\hline & + & - \\
\hline+ & 58 & 12 \\
\hline - & 1 & 63 \\
\hline
\end{tabular}




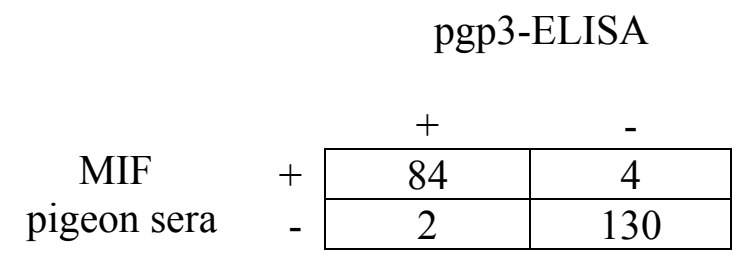

pgp3-ELISA

\begin{tabular}{lc|c|c|}
\multicolumn{1}{c}{ MIF } & + & + & - \\
\cline { 3 - 3 } human sera & - & 29 & 7 \\
\cline { 3 - 3 } & &
\end{tabular}

pgp3-WB

\begin{tabular}{|c|c|}
\multicolumn{1}{c}{+} & - \\
\hline 82 & 6 \\
\hline 2 & 130 \\
\hline
\end{tabular}

pgp3-WB

\begin{tabular}{|c|c|}
\multicolumn{1}{c}{+} & - \\
\hline 29 & 7 \\
\hline 4 & 10 \\
\hline
\end{tabular}

